\title{
Green infrastructure: innovative use of indigenous ecosystems and knowledge
}

\author{
Yosihiro Natuhara ${ }^{1}[$
}

Published online: 2 July 2018

(c) International Consortium of Landscape and Ecological Engineering and Springer Japan KK, part of Springer Nature 2018

\section{Introduction}

We held various meetings and two symposia on green infrastructure (GI), Joint Conference of Ecology and Civil Engineering Society, Japan Association of Landscape Ecology, and the Japanese Society of revegetation Technology, ecology landscape and revegetation (ELR) ELR2017 Nagoya and the 8th International Consortium of Landscape and Ecological Engineering (ICLEE), in September 2017. This issue includes two articles based on invited lectures at the first symposium "Landscape and Green Infrastructure." I also discuss papers on GI published in Landscape and Ecological Engineering.

The definitions of GI are numerous and diverse (Benedict and McMahon 2006). Infrastructure is defined as "The basic physical and organizational structures and facilities (e.g., buildings, roads, power supplies) needed for the operation of a society or enterprise" (Oxford English Dictionary). One definition of GI is "an interconnected network of natural areas and other open spaces that conserves natural ecosystem values and functions, sustains clean air and water, and provides a wide array of benefits to people and wildlife" (Benedict and McMahon 2002).

\section{Evolution of Gl}

At the symposium, "Landscape and Green Infrastructure" Ahern (2017) addressed the evolution of the concept of GI, which was first proposed in the 1980s and has undergone three phases of development.

Yosihiro Natuhara

natuhara@nagoya-u.jp

1 Graduate School of Environmental Studies, Nagoya University, Furo-cho, Chikusa-ku, Nagoya 464-8601, Japan
The first phase targeted ecological systems such as river corridors, and focused on connectivity at the landscape scale. It mainly covered suburban areas and the countryside. A definition of GI in this phase was given by Benedict et al. (2012).

The second phase was characterized by the application of GI to urban areas, not just to natural systems. Engineering measures were introduced for use in GI. The main target of this phase was flood water management, such as storm water management in Portland, Oregon. One definition of GI in this phase was physically and functionally integrated systems of grey and green infrastructure to support "working" cities and landscapes, while providing ecosystem services in a sustainable manner (Ahern 2017).

The third phase was concerned with explicit ecosystem services and was multifunctional. It aimed to integrate urban greening and urban policy. Bio-engineering was introduced into the concept GI, which utilizes various functions of plants and microorganisms in engineering. Examples of this approach include plant-based streambanks to produce a nonstatic bank line (Giordanengo et al. 2016), and improvement of urban soil using organic compost (Lin et al. 2017).

GI in the fourth phase focuses on cities that integrate novel urban ecosystems (Ahern 2016), i.e., ecosystems that persist in cities, structure by intentional or indirect management, which provide a suite of services. At this point GI became an adaptive design system utilizing bio-engineering to develop resilience in cities.

Anderson (2018) draws on a socioecological systems approach to outline four principles that can be applied to GI. Since cities are characterized by their dense populations, and their diverse needs often clash with respect to land use, multifunctional land use is required. Individual GI initiatives must take into consideration ecological, technical and social elements. At the same time, the local system must be linked to a broader system. 
Anderson's (2018) proposes four principles for functional GI. New functions need to be added to sites to which people attach a core function, e.g., a rain garden not only functions as a means of storm water treatment but also has aesthetic properties and is a habitat. The second principle is involvement: green spaces have developed through the interaction between human use and the response of nature over a long period; people learn from nature by participating in its management and use. Thirdly, at the landscape level, GI functions as an insurance against potential hazards, and has to be sustainable to meet this function. Finally, GI should be aimed at not only local solutions but also linked solutions at a regional scale.

For the design and use of GI, knowledge of urban ecosystems is essential, but are ecological theories that have been developed from studying natural ecosystems appropriate for an understanding of urban ecosystems? Paris (2018) argued that urban ecosystems, while displaying certain unique properties, can be understood through general ecological theories. Sixteen ecological theories were identified for application to urban environments, and recognizing the applicability of existing theories makes it possible to quickly design a better urban environment for both biodiversity and people.

\section{Gl in Japan}

GI is defined as infrastructure and land planning that contributes to the sustainable development of society and the economy by wisely using the multifunctionality of nature (Green Infrastructure Association 2017). In this context, responses to two earthquakes (experienced in 1995 and 2011) highlighted the hazard mitigation functions of urban greening (Hokugo 1997; Tanaka and Ogino 2017). In Japan, discussions on GI tends to focus on the feasibility of engineering, although a need for networks at the landscape scale is also recognized. Socioecological linkages at a landscape scale, such as between satoyama and satoumi (traditional rural territories and landscapes) contribute to building up resilience (Takeuchi et al. 2014). The Japanese government also recognizes GI in the national spatial strategy, stating that GI "aims to utilize the natural environment's diverse functions" and "obtain diverse effects such as improving local charm and the living environment and preventing/ reducing disasters" (Ministry of Land, Infrastructure, Transport and Tourism 2015). GI is also believed to be a means of promoting economic activities by utilizing local resources to develop, maintain, and manage infrastructure in a costeffective manner (Nishida 2017).

\section{GI in Landscape and Ecological Engineering}

Articles published in Landscape and Ecological Engineering cover water management, the urban environment, hazard mitigation, traditional knowledge, urban planning, and plant materials, which increase urban resilience by utilizing GI.

\section{Water management}

Kato and Ahern (2011) discussed the threshold concept, i.e., the relationship between impervious cover and various measures of stream degradation. Land use in watersheds affects water quality (Su et al. 2016). In China, losses of natural wetlands have led to ecological problems, such as soil degradation and biodiversity loss (Zheng et al. 2017). At a local level, Salix plantations in drawdown zones provided an excellent habitat for wildlife compared with bare, exposed soils (Azami et al. 2013). Restoration of biodiversity in wetlands has been attempted using safe sites (Muranaka 2009), soil seed banks (Nishihiro et al. 2006), and dam modification (Nakamura and Komiyama 2010).

\section{Urban climate}

Green spaces in Asian cities are decreasing due to a rapid increase in their populations (Byomkesh et al. 2012). For example, a number of problems of particular concern, including poverty, natural disasters, biodiversity loss, decreasing water quality and aesthetic degradation of landscapes, are connected to rapid changes in land use in Indonesia (Arfin and Nakagoshi 2011). Urban climate and inland flooding lower landscape functionality and the quality of urban life. Urban parks decrease air temperatures (Lee et al. 2009). Kim and Suh (2016) discussed climate change policies in Korea, and pointed out that the planning and design tools that have been created to aid the implementation of climate change policies do not tend to consider local characteristics. Green roofs are an effective tool for the mitigation of urban climates. Different plant materials used for roof cover have different thermal performances (Jim 2012). The selection of appropriate materials and methodologies for Mediterranean countries has been reported by Nektarios et al. (2014), who reviewed the decision-making process associated with the selection of materials for green roofs. Ishimatsu and Ito (2013) discussed brown/biodiverse roofs in the UK, i.e., the application of green roofs to brownfield, land that was previously developed for residential and industrial purposes, but has been abandoned and regenerated into different types of 
ecosystem (Lorimer 2008). There is also a possibility that brownfield areas will increase in urban areas of Japan and Korea facing population decline.

Rain gardens have been recommended as a management practice for the treatment of storm water runoff (US Evironental Protection Agency 2000). A case study using a simulation method reported that elements of GI are effective in detaining storm water and reducing the amount of runoff (Kim 2018). Ishimatsu et al. (2017) showed that rain gardens must be connected to a sewage system and require maintenance, such as garbage disposal.

\section{Hazard mitigation}

During the last decade tsunamis have had strong impacts in a number of countries. Several articles in Landscape and Ecological Engineering have reported the effects of coastal vegetation on disaster reduction (Chang et al. 2006; Rodriguez et al. 2016; Tanaka 2009; Tanaka et al. 2007, 2011; Tanaka and Ogino 2017; Tanaka and Onai 2017). For example, coastal vegetation mitigated the impact of a tsunami on coastal villages in Chile (Rodriguez et al. 2016). Mangroves and other trees have been found to be especially effective in providing protection from tsunami damage due to their complex aerial root structure (Tanaka et al. 2007), whereas the construction of hard infrastructure for tsunami protection is not feasible in many developing countries due to its high cost. The application of coastal vegetation can therefore be a feasible alternative for tsunami and general coastal protection in developing countries (Tanaka et al. 2011). Chang et al. (2006) emphasizes that importance of designs that consider the ecology and culture of the region in question for recovery after disasters.

\section{Traditional knowledge}

We should learn from traditional, regional knowledge and practices for sustainability plans. Morimoto (2011a) reported insights into creating a sustainable city from historical practices in Kyoto. These are (1) to conserve the surrounding landscape such as mountains, (2) create Japanese gardens for heterogeneity in the habitat to increase biodiversity, (3) use traditional gardens and wetland systems, which can play a role in the intelligent adaptation of landscapes to lower the risk of flooding.

With the exception of agriculture, improvement of riverine management by the planting of forests may have been the first instance of GI in Japan. The Dajokanfu governmental order instigated in $821 \mathrm{AD}$ was intended to protect land by regulating woodcutting by peasants. The order read: "If the mountain is stripped bold, the streams in the valleys will dry" (Totman 1989). Orders similar to this have been repeatedly instigated in Japan since then. The protection of catchment forests was aided by support from downstream participation in the Edo era (Kumazaki 1981). Fish-breeding forests first appeared in Japan in 947 AD (Wakana 2012) and, in the Edo period, the Murakami domain in Niigata prefecture prohibited the logging of a forest close to a river mouth because the forest created shade for spawning salmon (Niigata Prefecture 2010), http://www.pref.niigata.lg.jp/ murakami_norin/1288126813363.html).

Satoyama is a sustainable system of socioecologically important production landscapes in Japan. Morimoto (2011b) summarized the function of satoyama as that of a biodiversity hotspot, model for a sustainable society, and beautiful ancestral homeland. Satoyama landscapes protect the forest-village-river-sea linkage. At the same time, the conservation of a satoyama must not focus on the creation of static landscapes, but must instead be an active exercise in finding the appropriate means of allowing them to thrive (Yokohari and Bolthouse 2011). Horiuchi et al. (2011) reported a project that used local natural resources in a sustainable way to avoid further neglect or destruction of satoyama landscapes, which involved the participation of many stakeholders including the original satoyama management communities, local government, citizens, and non-governmental organizations.

Village landscapes have an advantage over more developed areas in China in the conservation of indigenous plant species (Wang et al. 2015). Many of the local native species in the hedges around villages are species also found in surrounding secondary forests. Traditional home gardens contribute greatly to the conservation of the genetic resources and cultural heritage in Japan (Fukamachi et al. 2011). The Tshimo gardens of the Batswana people are regarded as a model of resource management and indigenous knowledge (Davoren et al. 2016). Tshimo gardens usually include microgardens, e.g., vegetable plots, physic gardens for medicinal plants, ornamental gardens, open areas (lebala), natural areas (naga), and also structural species, which provide ecosystem services. However Tshimo gardens are often converted into more modern colonial gardens with rising in socioeconomic status.

Man-made ponds play an important role in rural landscapes in Asia. For example, there are 4606 household ponds comprising a total area of $7.2 \mathrm{~km}^{2}$ in Taking Hanfeng Lake Valley, in China (Chen et al. 2017). Besides being habitats for aquatic organisms, these household ponds also have an aesthetic function.

\section{Planning for multifunctional green spaces}

Ecosystem planning is the process of land use decisionmaking that considers the organisms and processes that characterize an ecosystem as a whole. Landscapes have come to be recognized as units for integration into 
ecosystem planning. Potential assessment is a method of estimating the potential of a local space or a landscape at the ecosystem or species' habitat scale (Natuhara 2006). Different types of green spaces can be used to create a system of GI in urban areas, and the quality of the system as a whole must be considered (Werner 2011). As Ignativa et al. (2011) states: "Urban ecological networks should respect, conserve and enhance natural processes. Developing countries are in the process of searching for their own approaches to creating GI and ecological networking that address their own local ecologies and cultural histories."

The main factor determining species richness and floral quality in cities is human impact (Rysiak and Czarnecka 2017). The highest number of species (including alien species) per square kilometer in urban areas is found in the transitional zones between the city center and rural areas, where the mosaic of land use types is most heterogeneous. Corridors are regarded as useful tools connecting fragmented habitats. Do et al. (2017) tested the effect of corridors (overpasses) on carabid beetles. Although carabid beetles were distributed in the corridors, species number was limited. The corridors acted as filters, and vegetation in these strongly affected the distribution of carabid beetles. Multifunctional GI planning has been proposed for a watershed with remnant mangroves in Rio de Janeiro (Herzog 2016), which includes not only the protection of environmental and economic benefits, but also improvements in food production and rural tourism.

\section{Plant materials}

GI is not a fixed system but a growing and changing one, in particular for forests. Sanesi et al. (2007) reported changes in urban forests and explored ways of sustaining the long-term integrity of forests in Parco Nord, Italy. Recovery is a key process of resilience, and Shang et al. (2014) investigated the recovery dynamics of post-disturbance forest communities, which they found primarily depended on external seed sources and resprouting from stumps. It is also important to note Shang et al.'s (2014) finding that disturbance contributes to species diversity across temporal and spatial scales in evergreen broadleaf forests in east China.

The naturalization of alien plant species has mainly occurred through horticulture and landscape design (Muller and Sukopp 2016), and landscape design also affects the invasion of alien plants. The incorporation of native biodiversity and the introduction of regional native plant material into new and existing parks and landscape designs can be important. In biodiversity-conscious landscape design, it is important to establish seed transfer zones based on genetic information (Tomita et al. 2017).

\section{Perspective}

Landscape and Ecological Engineering focuses on three major fields of landscape design: ecological engineering, landscape ecology, and landscape planning, which are fundamental to the successful implementation of GI. Landscape Ecological Engineering provides valuable theoretical and case studies of GI, and a special issue on the subject, "Ecological Resilience of Ecosystems to Human Impacts: Resilience of Plants and Animals," edited by one of the journal's editors, Junko Morimotois, is currently in progress. It aims to show the current state and direction of research necessary to increase ecological resilience through ecosystem management for the mitigation of intensifying natural disturbances.

We are grateful to all the authors, as well as the anonymous reviewers, who contributed to the two special issues. I am grateful to Prof. Dong Kun Lee for useful comments.

\section{References}

Ahern JF (2016) Novel urban ecosystems: concepts, definitions and a strategy to support urban sustainability and resilience. Landsc Archit Front 4:10-21

Ahern JF (2017) Green infrastructure: retrospect and prospect. In Landscape and Green Infrastructure, a key to sustainability. ELR2017 Nagoya symposium abstracts, pp 2-3

Anderson E (2018) Functional landscapes in cities: a systems approach. Landsc Ecol Eng. https://doi.org/10.1007/s11355-017-0346-6

Arfin HS, Nakagoshi N (2011) Landscape ecology and urban biodiversity in tropical Indonesian cities. Landsc Ecol Eng 7:33-43

Azami K, Fukuyama A, Asaeda T, Takechi Y, Nakazawa S, Tanida K (2013) Conditions of establishment for the Salix community at lower-than-normal water levels along a dam reservoir shoreline. Landsc Ecol Eng 9:227-238

Benedict MA, McMahon ET (2002) Green infrastructure: smart conservation for the 21st century. Renew Res J 20(3):12-17

Benedict MA, MacMahon ET, The Conservation Fund (2012) Green infrastructure linking landscapes and communities. Island, Washington DC

Byomkesh T, Nakagoshi N, Dewan AM (2012) Urbanization and green space dynamics in Greater Dhaka, Bangladesh. Landsc Ecol Eng $8: 45-58$

Chang HJ, Hargrove R, Long YX, Osborne DJ (2006) Reconstruction after the 2004 tsunami: ecological and cultural considerations from case studies. Landsc Ecol Eng 2:41-51

Chen C, Meurk CD, Jia Z, Lv M, Wu S, Jia J (2017) Incorporating landscape connectivity into household pond configuration in a hilly agricultural landscape. Landsc Ecol Eng 13:189-204

Davoren E, Siebert S, Cilliers S, du Toit MJ (2016) Influence of socioeconomic status on design of Batswana home gardens and associated plant diversity patterns in northern South Africa. Landsc Ecol Eng 12:129-139

Do Y, Kim Y, Kim HW, Joo GJ (2017) Distribution of carabid beetles within wildlife corridors connecting fragmented forests. Landsc Ecol Eng 13:279-286

Fukamachi K, Miki Y, Oku H, Miyoshi I (2011) The biocultural link: isolated trees and hedges in Satoyama landscapes indicate 
a strong connection between biodiversity and local cultural features. Landsc Ecol Eng 7:195-206

Giordanengo JH, Mandel RH, Spitz WJ, Bossler MC, Blazewicz MJ, Yochum SE, Jagt KR, LaBarre WJ, Gurnee GE, Humphries R, Uhing KT (2016) Living streambanks: a manual of bioengineering treatments for Colorado streams. Colorado Water Conservation Board, Denver

Green Infrastructure Association (2017) Green infrastructure. Nikkei, Tokyo

Herzog CP (2016) A multifunctional green infrastructure design to protect and improve native biodiversity in Rio de Janeiro. Landsc Ecol Eng 12:141-150

Hokugo A (1997) The performance of fire protection of buildings against the fires following the great Hanshin-Awaji earthquake. Fire Saf Sci 5:947-958. https://doi.org/10.3801/IAFSS .FSS.5-947

Horiuchi M, Fukamachi K, Oku H (2011) Reed community restoration projects with citizen participation: an example of the practical use of satoyama landscape resources in Shiga Prefecture, Japan. Landsc Ecol Eng 7:217-222

Ignativa M, Stewart GH, Meurk C (2011) Planning and design of ecological networks in urban areas. Landsc Ecol Eng 7:17-25

Ishimatsu K, Ito K (2013) Brown/biodiverse roofs: a conservation action for threatened brownfields to support urban biodiversity. Landsc Ecol Eng 9:299-304

Ishimatsu K, Ito K, Mitani Y, Tanaka Y, Sugahara T, Naka Y (2017) Use of rain gardens for stormwater management in urban design and planning. Landsc Ecol Eng 13:205-212

Jim CY (2012) Effect of vegetation biomass structure on thermal performance of tropical green roofs. Landsc Ecol Eng 8:173-187

Kato S, Ahern J (2011) The concept of threshold and its potential application to landscape planning. Landsc Ecol Eng 7:275-282

Kim J (2018) Exploring green infrastructure benefits at house and neighborhood scale: case study of Illinois, USA. Landsc Ecol Eng 14:165-174

Kim JO, Suh JH (2016) A review of climate change adaptation policies applied to landscape planning and design in Korea. Landsc Ecol Eng 12(1):171-177

Kumazaki M (1981) Suigenrin ni okeru karyu sanka no keifu (Genealogy of downstream participation in water source forest management). Water Sci 3:1-24 (in Japanese)

Lee SH, Lee KS, Jin WC, Song HK (2009) Effect of an urban park on air temperature differences in a central business district area. Landsc Ecol Eng 5:183-191

Lin BB, Philpott SM, Jha S, Liere H (2017) Urban agriculture as a productive green infrastructure for environmental and social well-being. In: Tan P, Jim C (eds) Greening cities. Advances in 21 st century human settlements. Springer, Singapore, pp $155-179$

Lorimer J (2008) Living roofs and brownfield wildlife: towards a fluid biogeography of UK nature conservation. Environ Plan 40:2042-2060

Ministry of Land, Infrastructure, Transport and Tourism (2015) National spatial strategy (national plan). www.mlit.go.jp/commo n/001127196.pdf. Accessed 8 June 2018

Morimoto Y (2011a) Biodiversity and ecosystem services in urban areas for smart adaptation to climate change: "Do you Kyoto"? Landsc Ecol Eng 7:9-16

Morimoto Y (2011b) What is Satoyama? Points for discussion on its future direction. Landsc Ecol Eng 7:163-171

Muller N, Sukopp H (2016) Influence of different landscape design styles on plant invasions in Central Europe. Landsc Ecol Eng 12:151-169

Muranaka T (2009) The restoration of gravelly floodplain vegetation and endemic plants to riparian habitat in a Japanese river. Landsc Ecol Eng 5:11-21
Nakamura F, Komiyama E (2010) A challenge to dam improvement for the protection of both salmon and human livelihood in Shiretoko, Japan's third Natural Heritage Site. Landsc Ecol Eng 6:143-152

Natuhara Y (2006) Landscape evaluation for ecosystem planning. Landsc Ecol Eng 2:3-11

Nektarios P, Ntoulas N, Paraskevpoulou AT, Zacharopoulou A, Chronopoulos I (2014) Substrate and drainage system selection and slope stabilization in an intensive-type roof garden park: case study of Athens Concert Hall. Landsc Ecol Eng 10:29-46

Niigata Prefecture (2010) Murakami-shi Iwagasaki-chiku no "Uotsuki hoanrin" ni tsuite (On fish-breeding forests at Iwagasaki district, Murakami City) http://www.pref.niigata.lg.jp/murakami_norin /1288126813363.html. Accessed 8 June 2018

Nishida T (2017) What is green infrastructure? Q J Public Policy Manage 2017(1):1-10 (in Japanese)

Nishihiro J, Nishihiro MA, Washitani I (2006) Restoration of wetland vegetation using soil seed banks: lessons from a project in Lake Kasumigaura, Japan. Landsc Ecol Eng 2:171-176

Paris KM (2018) Existing ecological theory applies in urban environments. Landsc Ecol Eng. https://doi.org/10.1007/s1135 5-018-0351-4

Rodriguez R, Encina P, Espinosa M, Tanaka N (2016) Field study on planted forest structures and their role in protecting communities against tsunamis: experiences along the coast of the Biobı'o Region, Chile. Landsc Ecol Eng 12:1-12

Rysiak A, Czarnecka B (2017) Richness of vascular flora in Lublin city, east Poland, under different urban pressure. Landsc Ecol Eng 13:213-228

Sanesi G, Lafortezza R, Marziliano PA, Ragazi A, Mariani L (2007) Assessing the current status of urban forest resources in the context of Parco Nord, Milan, Italy. Landsc Ecol Eng 3:187-198

Shang KK, Zhang QP, Da LJ, Hara K, Yang YC, Fujihara M, Tomita M, Zhao Y (2014) Effects of natural and artificial disturbance on landscape and forest structure in Tiantong National Forest Park, East China. Landsc Ecol Eng 10:163-172

Su WC, Ahern JF, Chang CY (2016) Why should we pay attention to "inconsistent" land uses? A viewpoint on water quality. Landsc Ecol Eng 12:247-254

Takeuchi K, Elmqvist T, Hatakeyama M, Kauffman J, Turner N, Zhou D (2014) Using sustainability science to analyse social-ecological restoration in NE Japan after the great earthquake and tsunami of 2011. Sustain Sci 9:513-526

Tanaka N (2009) Vegetation bioshields for tsunami mitigation: review of effectiveness, limitations, construction, and sustainable management. Landsc Ecol Eng 5:71-79

Tanaka N, Ogino K (2017) Comparison of reduction of tsunami fluid force and additional force due to impact and accumulation after collision of tsunami-produced driftwood from a coastal forest with houses during the Great East Japan tsunami. Landsc Ecol Eng 13:287-304

Tanaka N, Onai A (2017) Mitigation of destructive fluid force on buildings due to trapping of floating debris by coastal forest during the Great East Japan tsunami. Landsc Ecol Eng 13:131-144

Tanaka N, Sasaki Y, Mowjood MIM, Jinadasa KBSN, Homchuen S (2007) Coastal vegetation structures and their functions in tsunami protection: experience of the recent Indian Ocean tsunami. Landsc Ecol Eng 3:33-45

Tanaka N, Jinadasa KBSN, Mowjood MIM, Fasly MSM (2011) Coastal vegetation planting projects for tsunami disaster mitigation: effectiveness evaluation of new establishments. Landsc Ecol Eng 7:127-135

Tomita M, Kobayashi S, Abe S, Hanai T, Kawazu K, Tsuda S (2017) Phylogeography of ten native herbaceous species in the temperate region of Japan: implication for the establishment of seed transfer zones for revegetation materials. Landsc Ecol Eng 13:33-44 
Totman C (1989) The green archipelago: forestry in preindustrial Japan. University of California Press, Berkeley

US Environmental Protection Agency (2000) Low impact development (LID), a literature review. EPA-841-B-00-005. US Environmental Protection Agency, Washington, DC

Wakana H (2012) History of 'Uotsukirin' (fish-breeding forests) in Japan. In: Taniguchi M, Shiraiwa M (eds) The dilemma of boundaries: toward a new concept of catchment. Springer, Tokyo, pp $145-160$

Wang H, Qin J, Hu Y, Dong L, Chen JK (2015) Detecting the plant species composition and diversity among the farmers' settlement types in Shanghai. Landsc Ecol Eng 11:313-325
Werner P (2011) The ecology of urban areas and their functions for species diversity. Landsc Ecol Eng 7:231-240

Yokohari M, Bolthouse J (2011) Keep it alive, don't freeze it: a conceptual perspective on the conservation of continuously evolving satoyama landscapes. Landsc Ecol Eng 7:207-216

Zheng XJ, Sun P, Zhu WH, Xu Z, Fu J, Man WD, Li HL, Zhang J, Qin $\mathrm{L}$ (2017) Landscape dynamics and driving forces of wetlands in the Tumen River Basin of China over the past 50 years. Landsc Ecol Eng 13:237-250 